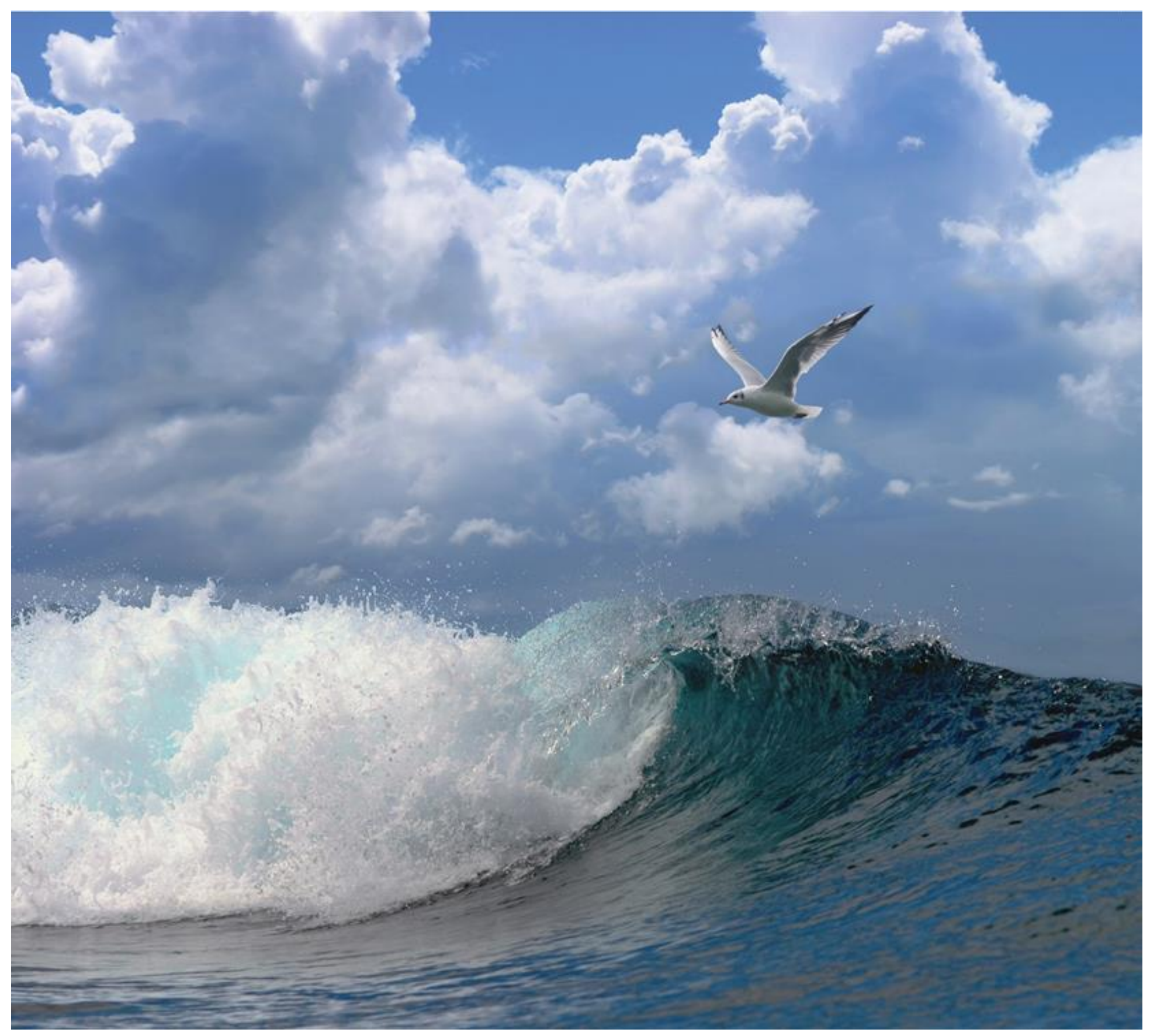

Passende Beoordeling ten behoeve van experimentele oesterkweek op Windgat percelen in de Kom van de Oosterschelde 


\section{Passende Beoordeling ten behoeve van experimentele oesterkweek op Windgat percelen in de Kom van de Oosterschelde}

Auteur(s): $\quad$ Pauline Kamermans

Publicatiedatum: 6 april 2017 
Pauline Kamermans, 2017. Passende Beoordeling ten behoeve van experimentele oesterkweek op Windgat percelen in de Kom van de Oosterschelde. Wageningen Marine Research Wageningen UR (University \& Research centre), Wageningen Marine Research rapport C031/17.

Keywords: oesterteelt, Oosterschelde, aquacultuur.

Opdrachtgever: Nederlandse Oestervereniging

T.a.v.: de heer Jaap de Rooij

's-Gravenpolderseweg 72

$4462 \mathrm{CH}$ Goes

Dit rapport is gratis te downloaden van https://doi.org/10.18174/412534.

Wageningen Marine Research verstrekt geen gedrukte exemplaren van rapporten.

Wageningen Marine Research Wageningen UR is ISO 9001: 2008 gecertificeerd.

\section{(C) 2016 Wageningen Marine Research Wageningen UR}

Wageningen Marine Research, onderdeel van Stichting Wageningen Research KvK nr. 09098104,

IMARES BTW nr. NL 8113.83.696.B16. Code BIC/SWIFT address: RABONL2U IBAN code: NL 73 RABO 0373599285
De Directie van Wageningen Marine Research is niet aansprakelijk voor gevolgschade, noch voor schade welke voortvloeit uit toepassingen van de resultaten van werkzaamheden of andere gegevens verkregen van Wageningen Marine Research opdrachtgever vrijwaart Wageningen Marine Research van aanspraken van derden in verband met deze toepassing.

Dit rapport is vervaardigd op verzoek van de opdrachtgever hierboven aangegeven en is zijn eigendom. Niets uit dit rapport mag weergegeven en/of gepubliceerd worden, gefotokopieerd of op enige andere manier gebruikt worden zonder schriftelijke toestemming van de opdrachtgever. 


\section{Inhoud}

Samenvatting

$1 \quad$ Inleiding

$2 \quad$ Te beoordelen activiteit $\quad 7$

$\begin{array}{llr}2.1 & \text { Locatiebepaling } & 7\end{array}$

2.2 Beschrijving van het project 8

2.2.1 Kweekopstellingen $\quad 8$

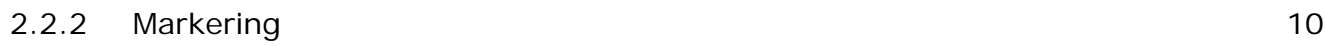

$\begin{array}{ll}2.2 .3 \text { Uitgangsmateriaal } & 10\end{array}$

$\begin{array}{lll}2.2 .4 & \text { Werkwijze } & 10\end{array}$

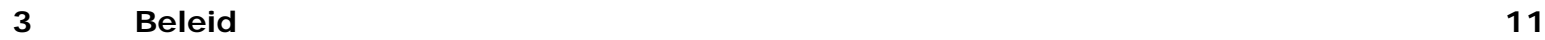

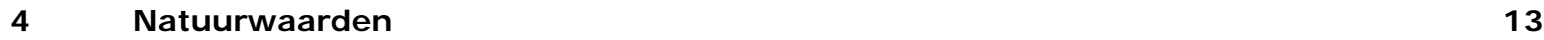

$\begin{array}{lll}4.1 & \text { Beschermde natuurwaarden en kenmerken } & 13\end{array}$

$\begin{array}{lll}4.2 & \text { Relevante beschermde natuurwaarden } & 15\end{array}$

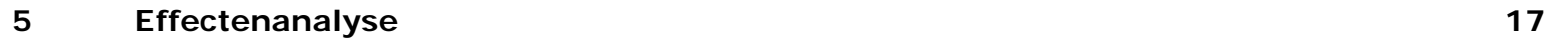

$\begin{array}{lll}5.1 & \text { Verstoring van beschermde soorten } & 17\end{array}$

$\begin{array}{ll}5.2 & \text { Verontreiniging } \\ 5.3 & 17\end{array}$

$\begin{array}{lll}5.3 & \text { Verandering dynamiek substraat } & 18\end{array}$

$\begin{array}{lll}5.4 & \text { Verandering soortensamenstelling } & 18\end{array}$

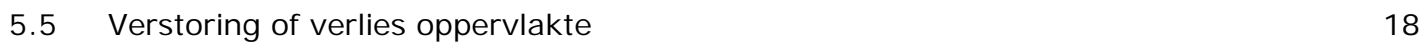

$\begin{array}{lll}5.6 & \text { Vogels } & 20\end{array}$

$\begin{array}{lll}5.7 & \text { Habitatsoorten } & 21\end{array}$

$6 \quad$ Mitigerende maatregelen $\quad 22$

$\begin{array}{llr}7 & \text { Cumulatieve effecten } & 23\end{array}$

8 Conclusie $r 2$

$\begin{array}{lr}\text { Kwaliteitsborging } & 25\end{array}$

$\begin{array}{lr}\text { Literatuur } & 26\end{array}$

$\begin{array}{lr}\text { Verantwoording } & 28\end{array}$

$\begin{array}{lll}\text { Bijlage } 1 & \text { Begeleiding OesterKweek eXperimenten (BOKX) } & 29\end{array}$ 


\section{Samenvatting}

Sinds 2010 is aangetoond dat er in de Oosterschelde sprake is van een oester herpes virus waardoor er met name bij de jonge oesters een veel hogere sterfte optreedt. Het virus manifesteert zich bij een watertemperatuur tussen 16 en $18{ }^{\circ} \mathrm{C}$. Het virus is in 2008 in Frankrijk aangetroffen en heeft daar tot grote sterfte van oesters geleid. Inmiddels zijn er aanwijzingen voor toenemende resistentie tegen het virus onder de oesters in Frankrijk. Daarnaast is er voor de oesterkweek in de Oosterschelde een probleem met geïntroduceerde oesterboorders die tot sterfte leiden van de oesters op de kweekpercelen.

Om te komen tot herstel van de oesterproductie hebben de Nederlandse Oestervereniging (NOV) en het ministerie van Economische Zaken een plan van aanpak geformuleerd om onder andere met behulp van nieuwe technieken de problemen te beheersen. De nieuwe technieken hebben allemaal betrekking op off-bottom kweek. De experimenten zullen worden begeleid door Wageningen Marine Research met onderzoek naar de effectiviteit en de effecten op de natuur.

Voor deze experimenten met off-bottom technieken dient de gebruikelijke vergunningprocedure voor activiteiten in Natura 2000-gebieden te worden doorlopen. Onderdeel van deze procedure is dat er een Passende Beoordeling wordt uitgevoerd waarin op basis van de best beschikbare kennis en informatie wordt getoetst of de beoogde activiteit geen wezenlijk negatief effect heeft op de instandhoudingsdoelen en daarmee de kernopgaven die in het aanwijzingsbesluit voor het betreffende Natura 2000-gebied zijn geformuleerd.

De activiteiten die gerelateerd zijn aan experimentele oesterkweek op de oesterpercelen Windgat 13, 14 en 16 in het sublitoraal van Kom van de Oosterschelde zijn geanalyseerd wat betreft de effecten op de instandhoudingsdoelstellingen van habitats en beschermde soorten. Ook is ingegaan op mitigerende maatregelen en cumulatieve effecten.

In voorliggende Passende Beoordeling is de beschikbare informatie samengevat. De conclusie is dat er geen als significant te beoordelen negatieve effecten zijn te verwachten van experimentele oesterkweek op de oesterpercelen Windgat 13, 14 en 16 in het sublitoraal van Kom van de Oosterschelde. Dit geldt zowel voor de Natura 2000-instandhoudingdoelen van habitats en soorten als voor aan de orde zijnde verbeteropgaven voor het Natura 2000 gebied de Oosterschelde. 


\section{$1 \quad$ Inleiding}

In de kom van de Oosterschelde vindt de kweek van Japanse oesters (Magallana gigas) plaats op kweekpercelen op de bodem, voornamelijk beneden laagwater. In totaal is er 1550 ha perceelgrond verhuurd, maar niet alle percelen zijn in gebruik. De kweek bestaat uit het invangen van oesterbroed met behulp van lege (mossel)schelpen waarop het jonge oesterbroed zich vasthecht. De schelpen worden voor de broedval uitgezaaid op broed-invang percelen en in een tijdbestek van ca 9 - 12 maanden opgevist en verplaatst naar percelen voor de opkweek. De opbrengst wordt geschat op 3 mln kg oesters per jaar; dit correspondeert met een geschatte bestandsgrootte van $10 \mathrm{mln}$ kg (Smaal et al, 2013).

Door twee recentelijk opgetreden bedreigingen zijn de oesterkwekers op zoek naar nieuwe kweekmethoden (Wijsman et al, 2015).

Sinds 2010 is er in de Oosterschelde sprake van een oester herpes virus waardoor er met name bij de jonge oesters een veel hogere sterfte optreedt. Het virus manifesteert zich bij een watertemperatuur tussen 16 en $18{ }^{\circ} \mathrm{C}$. Het virus is in 2008 in Frankrijk aangetroffen en heeft daar tot grote sterfte geleid; inmiddels zijn er aanwijzingen voor toenemende resistentie bij de oesters in Frankrijk Kamermans et al, 2013; Dundon et al, 2011).

Daarnaast is er een probleem met oesterboorders die in de Oosterschelde zijn geïntroduceerd, nl. de J apanse oesterboorder Ocenebra inornata en de Amerikaanse oesterboorder Urosalpinx cinerea (Fig. 1 en 2). De eerste meldingen van de Japanse oesterboorder dateren van 2007 (Faase \& Ligthart, 2009), maar het is mogelijk dat de slak al langer aanwezig is en niet eerder correct is gedetermineerd (Faase \& Ligthart, 2009). De Amerikaanse oesterboorder is tot nu toe alleen aangetroffen op 1 locatie in de Oosterschelde, bij Gorishoek.
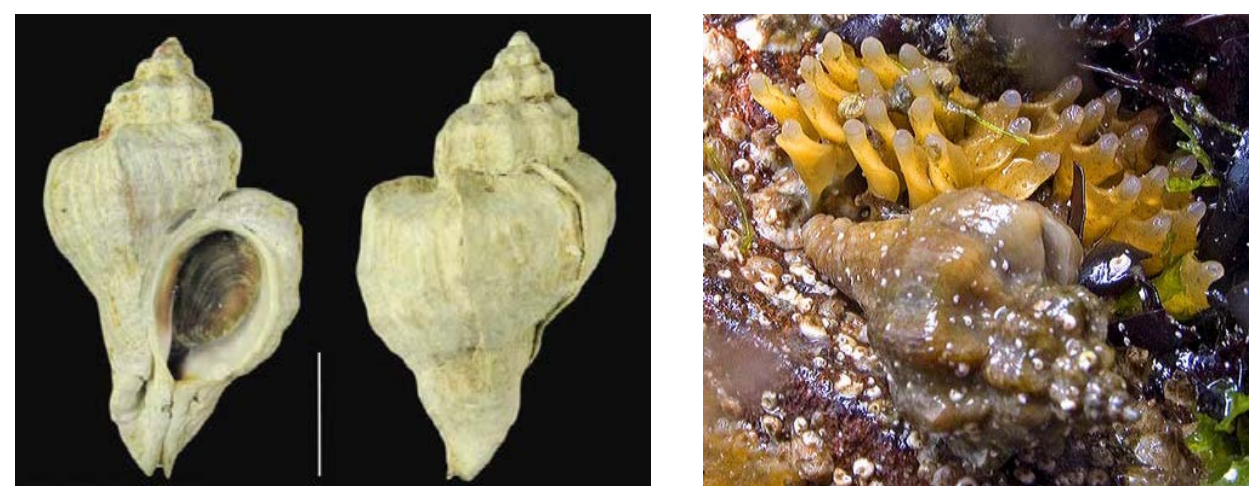

Fig 1. Ocenebra inornata (foto: L. Schroeder, found at http://www.bily.com). Rechts: ei capsules en slak (Image: http://www.cryptosula.nl).
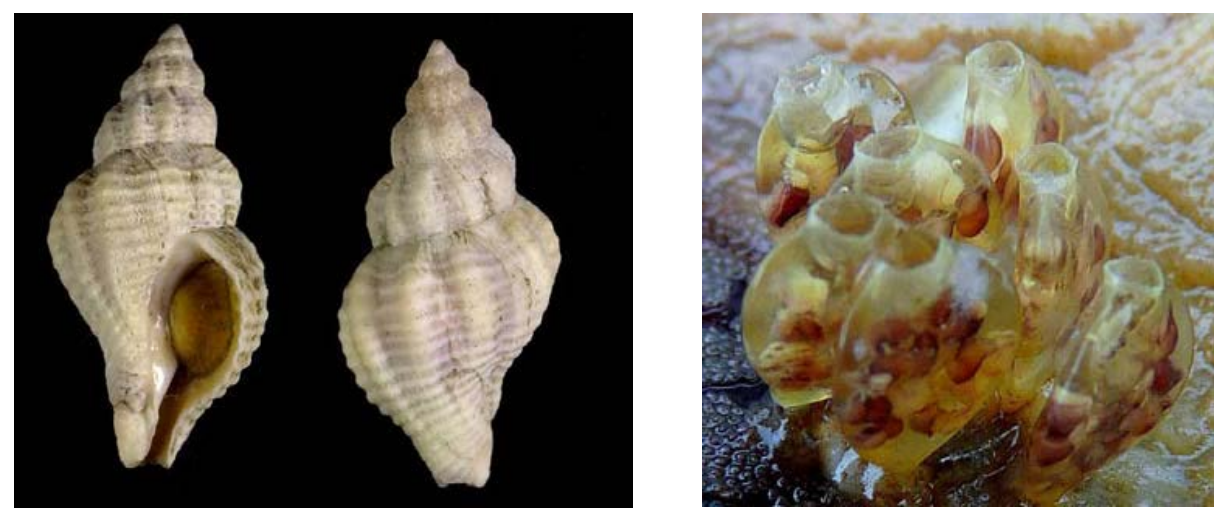

Fig 2. Urosalpinx cinerea (foto: BISHOGAl Data Base http://shell.kwansei.ac.jp). Rechts: ei capsules met jonge slakjes nabij Gorishoek, The Netherlands (foto. A. H.M. Ligthart (Faasse \& Ligthart 2009). 
De J apanse oesterboorder is in de periode 2007 - 2013 aangetroffen in de oesterputten in Yerseke en nabij Gorishoek. Een recente inventarisatie laat zien dat de slakken nu ook worden aangetroffen in de Kom, de Dortsman, het Prinsenplaatje, de Zandkreek, de Galgenplaat en de Noordelijke tak (van Stralen et al, 2015).

Vanuit de praktijk van de oesterkwekers wordt gemeld dat de overleving van oesterbroed sinds 2013 veel te leiden heeft van het herpesvirus. Verder worden er veel slakken en ook regelmatig ei pakketten aangetroffen op en nabij oesters, en veel schelpen met een boorgat, waardoor van de broedjes die het virus overleven vervolgens weinig terecht komt door predatie door de boorders. De combinatie van beide vijanden leidt nu tot grote problemen in de oesterkweek (Strietman et al, 2016). Om te komen tot herstel van de oesterproductie hebben de Nederlandse Oestervereniging (NOV) en het ministerie van Economische Zaken een plan van aanpak geformuleerd om onder andere met behulp van nieuwe technieken de problemen te beheersen (NOV, 2016; Smaal et al., 2016). De nieuwe technieken bestaan uit off-bottom kweek.

De Oosterschelde is aangewezen als Natura-2000 gebied (Ministerie van LNV, 2009), waarvoor een ontwerp beheerplan (2015 - 2021) is opgesteld (Min IenM, 2015). Het Natura 2000-gebied Oosterschelde omvat de het buitendijks gebied en een aantal aangrenzende binnendijkse gebieden, zoals de inlagen aan de zuidkust van Schouwen. Voor de nieuwe activiteit dient de gebruikelijke vergunningprocedure voor activiteiten in Natura 2000-gebieden te worden doorlopen. Onderdeel van deze procedure is dat er een Passende Beoordeling (verder PB genoemd) wordt opgesteld waarin op basis van de best beschikbare kennis en informatie wordt getoetst of de beoogde activiteit geen wezenlijk negatief effect heeft op de instandhoudingsdoelen en daarmee de kernopgaven die in het aanwijzingsbesluit (Ministerie van LNV, 2009) voor het betreffende Natura 2000-gebied zijn geformuleerd.

Voor experimenten in het sublitoraal met zakken in kooien op de bodem of aan longlines in het sublitoraal van de Kom van de Oosterschelde is voor de NOV door WMR (IMARES) een Passende Beoordeling opgesteld (Kamermans \& Smaal, 2016). Een NB wet vergunning is verleend (kenmerk DGAN-NB / 16052053). De experimenten worden begeleid met onderzoek naar de effectiviteit en de effecten op de natuur. In aanvulling op de vergunde locaties (West van HK 10 West van HK 18, HK 10, HK 11, HK 18, YB 685 en YB 686) heeft een consortium van oesterkweekbedrijven (Groep Vette, bestaande uit de Oestervisser BV, Jan Vette BV en J.P. Dhooge BV) het voornemen een proef op een andere locatie in het sublitoraal uit te voeren. Door op zoveel mogelijk verschillende locaties proeven te doen kunnen de resultaten van de verschillende locaties worden vergeleken. Dit is vooral van belang voor het invangen van broed en de sterfte als gevolg van het oesterherpesvirus. Een dergelijke vergelijking geeft de kwekers meer inzicht in de voor- en nadelen van het gebruik van verschillende locaties en methoden in de Oosterschelde. Dit betreft zowel ervaring met de techniek in relatie tot de ontwikkeling van de oesters, als inzicht in de bedrijfseconomische aspecten. Het gaat bijvoorbeeld om het verifiëren van de benodigde inspanning, welke materialen de beste resultaten geven (mandje of zakken), welk schip het beste voldoet.

Voorliggende PB kan worden gebruikt bij de aanvraag, en door het bevoegd gezag (Ministerie van Economische Zaken) bij het opstellen en verlenen van de benodigde vergunning in het kader van de Natuurbeschermingswet 1998. 


\section{Te beoordelen activiteit}

\section{$2.1 \quad$ Locatiebepaling}

De Groep Vette is voornemens om oesters met nieuwe off-bottom technieken te gaan kweken op 3 percelen in het Windgat (perceelnummers 13, 14 en 16) in de Kom van de Oosterschelde (Fig. 3). Deze percelen zijn momenteel in gebruik als oesterkweekpercelen. In het totaal gaat het om 2 ha benut oppervlak (dit is inclusief werkruimte en een veiligheidszone). Deze ruimte zal pas geleidelijk in gebruik genomen gaan worden, mede afhankelijk van de bevindingen tijdens de experimentele fase.

Het gebied Oosterschelde is een onderdeel van het voormalige estuarium van de Schelde. In 1986 is de Oosterschelde van de Noordzee afgesloten door een stormvloedkering. Tevens zijn er compartimenteringsdammen aangelegd om het getijvolume te beperken. Door deze deltawerken is de Oosterschelde veranderd in een ondiepe baai met zout water en gedempt getij. De huidige Oosterschelde bestaat uit een complex geheel van kreken, onder water staande zandbanken, droogvallende slikken en platen en begroeide, periodiek overstroomde schorren. Het gebied vormt, samen met binnendijkse gebieden, een bijzonder rijk leefmilieu voor flora en fauna. Vooral de ondiepe wateren en het intergetijdengebied zijn rijk aan ongewervelden, dat weer dient als voedsel voor vogels en grotere zeedieren. De dagelijks droogvallende slikken en platen van de Oosterschelde zijn van groot internationaal belang voor foeragerende watervogels, met name voor steltlopers, eendachtigen en meeuwen. De oppervlakte aan buitendijks gebied in de Oosterschelde buitendijks bedraagt 351 $\mathrm{km}^{2}$. Daarvan is $112,5 \mathrm{~km}^{2}$ intergetijdengebied. De oppervlakte van Natura 2000 -gebied Oosterschelde (inclusief binnendijkse gebieden) is $370 \mathrm{~km}^{2}$.

Als gevolg van de getijdestromen vinden erosie- en sedimentatieprocessen plaats die resulteren in een wisselend patroon van schorren, slikken en droogvallende platen (het intergetijdengebied), ondiep water en diepe getijdengeulen. In de monding van de Oosterschelde bevinden zich de diepste stoomgeulen die plaatselijk een diepte van 45 meter bereiken. Tussen deze stroomgeulen en in het gebied ten oosten van de Zeelandbrug bevinden zich uitgestrekte gebieden met ondiepe wateren met zandbanken. In het oosten en noorden van het gebied komen grote oppervlakten slikken voor. Binnendijks worden langs de oever een groot aantal karrevelden inlagen en kreekrestanten tot het gebied gerekend. Deze gebieden bestaan voornamelijk uit vochtige graslanden en open water. Het water, het intergetijdengebied en de binnendijks gelegen gebieden vormen tezamen het leefmilieu voor de rijke flora en fauna van het gebied. De grote variatie aan milieutypen in het gebied gaat gepaard met een grote diversiteit aan dier- en plantensoorten. Genoemde variatie aan milieutypen wordt bepaald door factoren als getij, stroming, watertemperatuur, hoogteligging, waterkwaliteit en sedimentsamenstelling.

Een specifiek probleem van de Oosterschelde is de zogenaamde 'zandhonger' (Van Maldegem, 2004). Door de bouw van de stormvloedkering is het morfologisch evenwicht van de Oosterschelde verstoord. Het getijvolume is vermindert en de huídige afmetingen van de geulen zijn aan deze afname nog niet aangepast. Zolang de opvulling van de geulen niet is gerealiseerd en de Oosterschelde niet haar nieuwe evenwicht heeft bereikt zal de Oosterschelde lijden aan zandhonger, waardoor de slikken en platen eroderen en het totaal oppervlakte aan intergetijdengebied zal afnemen. 


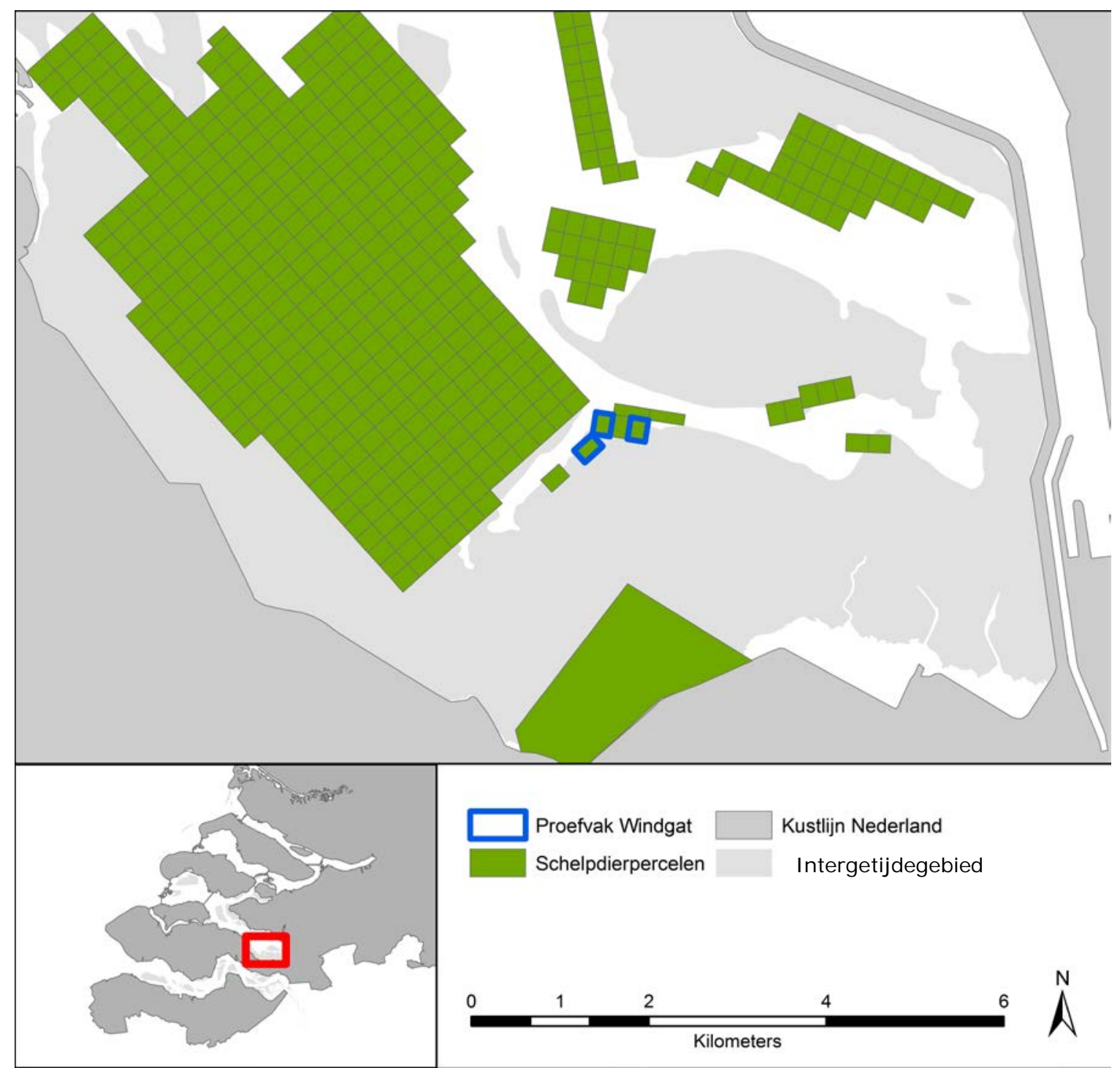

Fig. 3. Beoogde locatie voor het kweekexperiment op Windgat perceelnummers 13, 14 en 16.

\subsection{Beschrijving van het project}

\subsubsection{Kweekopstellingen}

De oesters worden gekweekt in zakken en mandjes. De zakken worden geplaatst in kooien (Fig. 4). Het kweken van oesters in zakken is een methode die in Frankrijk veel wordt gehanteerd. Het komt erop neer dat kunststof zakken die zijn gevuld met oesters op een frame (tafel) van betonijzer worden gelegd. De zakken worden aan het frame vastgemaakt. Een zak is ca. $100 \times 50 \mathrm{~cm}\left(0,5 \mathrm{~m}^{2}\right)$. Gebruik van zakken in kooien is een nieuwe teeltmethode. ledere kooi heeft 20 zakken en de verwachting is dat een zak bij oogst 12,5 kg oesters bevat. Er wordt gebruik gemaakt van dubbele (duo) kooien. Duo-kooien zijn twee kooien zoals uit figuur 4 die naast elkaar aan elkaar vast zijn gemaakt. De kooien staan aan de geulzijde van de percelen op de bodem onder de laagwaterlijn en de bovenkant steekt met laagwater boven het water uit. Er worden 3 rijen van 100 duo-kooien geplaatst. In het totaal nemen de kooien niet meer dan 10 tot $20 \%$ van het perceel oppervlak in beslag. Daarnaast wordt een ander systeem getest, namelijk kweek in oestermanden (Fig. 5). Dit is een systeem dat in Australië is ontwikkeld. De manden zijn bevestigd aan longlines (Fig. 6). Aan 1 longline kunnen 1500 mandjes hangen. Er worden 3 longlines geplaatst op de locatie. De longlines worden verankerd met ankers en drijvend gehouden met grijze drijvers zoals ook gebruikt voor MZI's. De manden worden ook geplaatst in 3 rijen van 100 duo-kooien. ledere kooi heeft 20 mandjes. De manden bevatten bij 
oogst een verwachtte massa van $14 \mathrm{~kg}$ oesters. Per perceel zal 1 longline en 2 rijen met duo kooien op het diepste deel van het perceel worden geplaatst. Het benut oppervlak per longline is $4.800 \mathrm{~m}^{2}$ en per rij van 100-duo kooien is dat $1.000 \mathrm{~m}^{2}$. In totaal wordt ernaar verwachting een voorraad gekweekt van maximaal $381.000 \mathrm{~kg}$ (300 duo-kooien met totaal 12.000 zakken, 300 duo-kooien met totaal 12.000 mandjes en 3 longlines met totaal 4.500 mandjes, dat is totaal $381.000 \mathrm{~kg}$ bij oogst). Deze teelt vervangt de teelt op de bodempercelen. Bij gebruik als bodemperceel hadden de percelen een voorraad van maximaal $144.000 \mathrm{~kg}$ bevat. De extra aanwezige biomassa is dus lokaal $237.000 \mathrm{~kg}$ meer. Ten opzichte van een totale geschatte voorraad op de percelen van $10 \mathrm{mln} \mathrm{kg}$ is dat 2,4 \%.

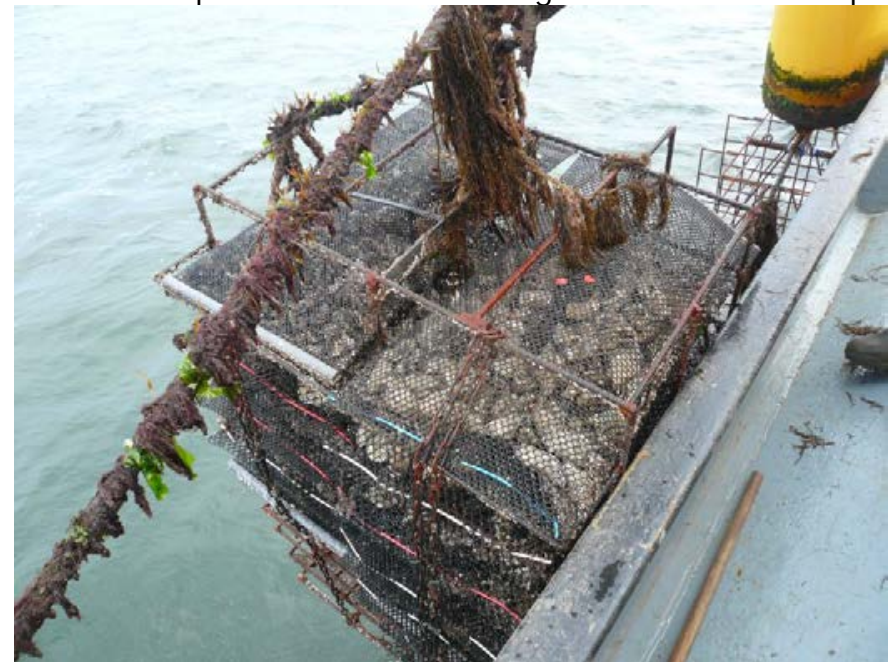

Fig. 4. Kooi met zakken voor off-bottom cultuur van oesters.

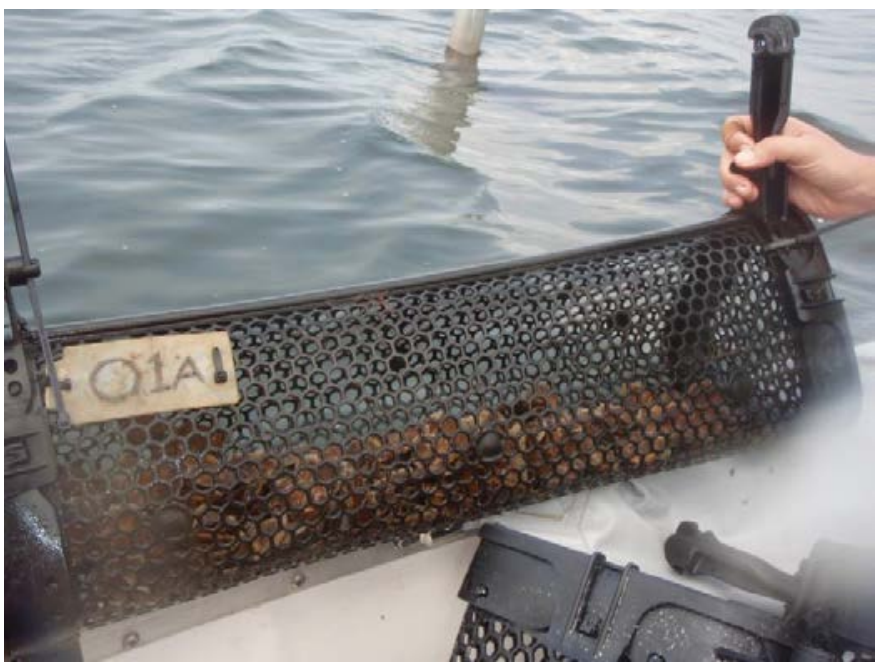

Fig. 5. Mandje voor off-bottom cultuur van oesters.

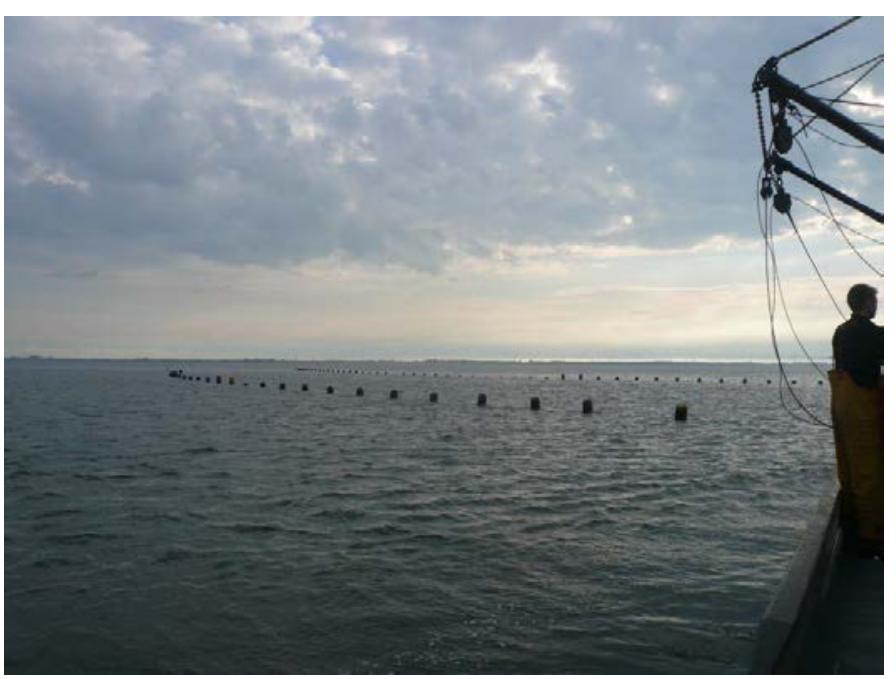

Fig. 6. Twee longlines voor off-bottom cultuur van oesters. 


\subsubsection{Markering}

De installaties bevinden zich op reguliere oesterkweekpercelen die zijn gemarkeerd door middel van bakens. In dit deel van de Kom van de Oosterschelde bevinden zich geen doorgaande vaarwegen. Op de plaats van de installaties is geen scheepvaart, m.u.v. de eigen boot.

\subsubsection{Uitgangsmateriaal}

Als uitgangsmateriaal worden kleine oesters en oesterbroed gebruikt afkomstig van de reguliere oesterkweek en van visserij op de vrije gronden waar reeds vergunning voor is verleend.

\subsubsection{Werkwijze}

Er wordt vanaf een ondiep oesterschip rondom hoogwater gewerkt. In april worden de kweekinstallaties geplaatst. In het voorjaar worden de manden en zakken geleidelijk gevuld met beschikbare oesters. Afhankelijk van de groei worden de oesters geleidelijk verdeeld over meer zakken en mandjes (uitdunnen). De zakken en mandjes worden voor $1 / 3$ e deel gevuld met kleine oesters. Zodra deze zoveel zijn gegroeid dat de helft van de zak/mandje is gevuld, wordt een deel van de oesters overgebracht in een lege zak/mandje, zodat de zak/mandje opnieuw voor 1/3e is gevuld. Dat proces herhaalt zich totdat de oesters de consumptiegrootte hebben bereikt. Gedurende de zomer en het najaar worden de oesters regelmatig gesorteerd op grootte, de consumptie oesters worden geoogst, de kleinere oesters worden weer teruggebracht in de manden en zakken. In de winterperiode is de verwachting dat een deel van de oesters terug kan worden gezaaid op de percelen, in de hoop dat door de lage watertemperatuur de oesterboorders minder/niet actief zullen zijn.

In de periode van januari - november wordt verwacht dat er één maal per 2 weken gedurende 2 - 3 uur (afhankelijk van het aantal zakken en mandjes) activiteiten zullen zijn. In de periode november half december zal er meerdere dagen per week gedurende 2 - 4 uur per dag activiteit zijn. De activiteiten zijn samengevat in tabel 1 . Op de locatie zal het schip stil liggen om de werkzaamheden aan de zakken en manden te kunnen uitvoeren.

Tabel 1. Inschatting frequentie en duur activiteiten op oesterpercelen

\begin{tabular}{|l|l|l|l|}
\hline Activiteit & Frequentie & Tijdsduur en tijdstip & Periode \\
\hline plaatsen kweekinstallaties & eenmalig in eerste jaar & $\begin{array}{l}6 \text { uur bij daglicht rondom } \\
\text { hoogwater }\end{array}$ & april/mei \\
\hline $\begin{array}{l}\text { onderhoud kweekinstallaties } \\
\text { aangroei verwijderen } \\
\text { uitdunnen }\end{array}$ & één maal per 2 weken & $\begin{array}{l}2-3 \text { uur bij daglicht rondom } \\
\text { hoogwater }\end{array}$ & april/mei - november \\
\hline belangrijkste oogst periode & 3 dagen per week & $\begin{array}{l}2-4 \text { uur bij daglicht rondom } \\
\text { hoogwater }\end{array}$ & november - december \\
\hline
\end{tabular}




\section{Beleid}

\section{Beleidsbesluit schelpdiervisserii}

Door de minister van LNV wordt in het Beleidsbesluit Schelpdiervisserij 2005-2020 (Ministerie van LNV, 2004) ruimte gegeven om te experimenteren met alternatieve en duurzame nieuwe kweekvormen. In het Beleidsbesluit 2005-2020 is met betrekking tot de kweek van schelpdieren (hfdst 4.3) het navolgende opgenomen:

I nitiatieven om ook andere soorten zoals St. J acobsschelpen, Venusschelpen en Japanse oesters te kweken zullen op hun inpasbaarheid binnen de bestaande kaders worden beoordeeld. Op voorhand wordt vanuit een positieve grondhouding naar dit soort initiatieven gekeken. Nieuwe kweekvormen zullen vooraleerst alleen onder experimentele omstandigheden (kleinschalig en begeleid door onderzoek) mogen plaatsvinden

Een experiment met het op een alternatieve wijze kweken van schelpdieren past derhalve in het beleid van de minister van EZ. Voorwaarde is wel dat het duurzaam is, kleinschalig, passend binnen de natuurlijke mogelijkheden en wordt begeleid door onderzoek.

Om de recente problemen in de oesterkweek gezamenlijk het hoofd te kunnen bieden, wordt de komende periode ingezet op maatregelen voor de korte termijn, de middellange en lange termijn zoals beschreven in Plan van Aanpak 'Oester-maatregelen' 2016 - 2018 (NOV, 2016). Om de oesterboorders te ontlopen valt in eerste instantie te denken aan het invangen en kweken in de waterkolom ("off-bottom"). Off-bottom-technieken die hier voor in aanmerking komen zijn:

- Mandjes, die met name in het litoraal kunnen worden gebruikt, maar deze kunnen ook aan een longline in het sublitoraal worden gebruikt.

- $\quad$ Rekken en tafels, waarop zowel in het litoraal als in het sublitoraal zakken met oesters worden gelegd voor verdere opkweek. Met deze technieken is in de Nederlandse wateren nog weinig ervaring opgedaan, zodat aan de hand van nadere experimenten meer informatie wordt verkregen over de consequenties met betrekking tot onder meer 'lichtinval', 'schaduwwerking' en 'leefgebied en soorten'.

- Staande kweekkooien, die op de bodem in zowel het litoraal als het sublitoraal kunnen worden geplaatst. Ook bij deze technieken kan aan de hand van experimenten meer informatie worden verkregen over de consequenties met betrekking tot onder meer 'lichtinval', 'schaduwwerking' en 'leefgebied en soorten'.

- Hangende kweekkooien, die in het sublitoraal aan longlines zijn bevestigd.

\section{Natura 2000}

De Oosterschelde is op 23 december 2009 door de minister van Landbouw, Natuur en Voedselkwaliteit (LNV, nu Economische Zaken: EZ) definitief aangewezen als Natura 2000-gebied (gebiedsnummer 118: Oosterschelde). Met het oog op deze aanwijzing, dienen activiteiten die als plan of project volgens art. 6: 3 van de Habitatrichtlijn (richtlijn 92/43IEEG) kunnen worden aangemerkt, te worden beoordeeld op hun effecten op de instandhoudingdoelstellingen van het gebied.

\section{Provinciaal Sociaal-Economisch Beleidsplan 2009-2012}

In dit plan wordt geconstateerd dat achterblijvende groei van oesters leidt tot verlies van marktaandeel. Verbetering van de kansen voor verschillende vormen van schelpdiercultuur in de Deltawateren vormt één van de prioriteiten voor de Provincie Zeeland.

\section{Ontwerpbeheerplan Deltawateren}

Via dit beheerplan (Van Bentum \& Koolmees, 2014) is de oesterteelt onder specifieke voorwaarden vrijgesteld van de $\mathrm{Nb}$-wet vergunningplicht. De oesterhangcultuur en de experimentele oesterkweek 
met diverse methoden blijft echter een vergunningplichtige activiteit. De oesterkweek vindt plaats op daartoe bestemde oesterpercelen in de Oosterschelde die door het Rijk worden verhuurd.

\section{Vooronderzoek ten behoeve van de passende beoordeling ex artikel 6 lid 3 Habitatrichtlijn}

Het project bestaat uit het opkweken van oesters met behulp van mandjes en zakken in het Natura 2000-gebied Oosterschelde, volgens de hierboven omschreven werkwijze. Uitvoering van het onderhavige project betreft een activiteit welke niet direct verband houdt met, of nodig is voor het beheer van het Vogel- en Habitatrichtlijngebied Oosterschelde.

Artikel 6, derde lid, van de Habitatrichtlijn bevat een toetsingskader voor plannen en projecten in of nabij de op grond van de Habitatrichtlijn beschermde gebieden en, via de schakelbepaling van artikel 7 van de Habitatrichtlijn, de op grond van de Vogelrichtlijn beschermde gebieden.

In artikel 6, derde lid, van de Habitatrichtlijn is bepaald dat voor elk plan of project dat niet direct verband houdt met of nodig is voor het beheer van een op grond van deze richtlijn beschermd gebied en afzonderlijk of in combinatie met andere plannen of projecten significante gevolgen kan hebben voor dat gebied, een analyse van de gevolgen voor dat gebied moet worden gemaakt. Hierbij dient rekening te worden gehouden met de instandhoudingsdoelstellingen van dat gebied en geldt dat de bevoegde nationale instanties slechts toestemming voor het betrokken plan of project geven nadat zij op basis van de analyse de zekerheid hebben verkregen dat de natuurlijke kenmerken van het betrokken gebied (met het oog waarop het gebied is aangewezen) niet zullen worden aangetast. Ten behoeve van deze PB is gekeken naar die soorten en habitattypen welke als kwalificerend zijn aangemerkt met betrekking tot de, binnen de Oosterschelde vallende, Vogel- en Habitatrichtlijngebieden. 


\section{$4 \quad$ Natuurwaarden}

\subsection{Beschermde natuurwaarden en kenmerken}

Het Natura 2000-gebied de Oosterschelde heeft een totaal oppervlak van 36.980 ha en bevat zowel een buitendijks als een binnendijks (inlagen, karrevelden, kreekrestanten, eendenkooien) gebied (Ministerie van LNV, 2009). De Oosterschelde is een voormalig estuarium dat in 1986 is afgesloten van de Noordzee door middel van de Oosterscheldekering. Tevens zijn er compartimenteringsdammen aangelegd om het getijvolume te beperken. Door deze Deltawerken is de Oosterschelde veranderd van een estuarium naar een ondiepe baai met zout water en gedempt getij. De droogvallende slikken en platen vormen een belangrijk onderdeel van de getijdennatuur in Zuidwest Nederland.

De huidige Oosterschelde bestaat uit een complex geheel van geulen, onder water staande zandbanken, droogvallende slikken en platen en hoger gelegen schorren. Het gehele aquatische gebied wordt gerekend tot het habitattype H1160 (Grote, ondiepe kreken en baaien, verkorte naam Grote baaien), terwijl de habitattypen buitendijkse schorren (H1330A), slijkgrasvelden (H1320) en zilte pionierbegroeiingen (H1310A) apart zijn aangewezen (Janssen \& Schaminée, 2009). De Oosterschelde is een belangrijk leefgebied voor kustbroedvogels, moerasbroedvogels en doortrekkende en overwinterende watervogels. De Oosterschelde is voor een tweetal habitatsoorten aangewezen: de Gewone zeehond (H1365) en de Noordse woelmuis (H1340).

In het doelendocument (Troost \& Van Hulzen, 2009) is voor de Oosterschelde een aantal kernopgaven geformuleerd:

- Behoud van slikken en platen voor rustende en foeragerende niet-broedende vogels en rustgebieden voor zeehonden;

- Behoud en herstel van schorren en zilte graslanden (buitendijks) met alle successiestadia, zoet-zout overgangen, verscheidenheid in substraat en getijregime en als hoogwatervluchtplaats;

- Behoud en ontwikkeling van kwaliteit binnendijkse brakke gebieden voor Noordse woelmuis en voor broedvogels (Kluut, sterns) en als hoogwatervluchtplaats, overgangs- en trilvenen (veenmosrietlanden) brakke variant van ruigten en zomen (Harig wilgenroosje), schorren en zilte graslanden (binnendijks) en als hoogwatervluchtplaats.

Deze kernopgaven zijn in het aanwijzingsbesluit Oosterschelde (Ministerie van LNV, 2009) vertaald in een aantal instandhoudingsdoelen (Tabel 2).

Tabel 2. Lijst met habitattypen en soorten waarvoor de Oosterschelde is aangewezen, met bijhorende instandhoudingsdoelstellingen. =: behoud doelstelling omvang en kwaliteit. >:

uitbereidingsdoelstelling areaal of verbeterdoelstelling kwaliteit (Ministerie van LNV, 2009). *Voor de Gewone zeehond is een regionaal doel gesteld van ten minste 200 exemplaren in het Deltagebied (Ministerie van LNV, 2009).

\begin{tabular}{|c|c|c|c|c|}
\hline & & \multicolumn{3}{|c|}{ Gebiedsdoelstelling } \\
\hline & & 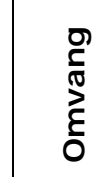 & 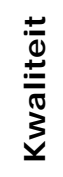 & $\begin{array}{l}\stackrel{0}{+} \\
\frac{\pi}{3} \\
\frac{0}{0}\end{array}$ \\
\hline Code & Habitattypen & & & \\
\hline H1160 & Grote baaien & $=$ & $>$ & \\
\hline $\mathrm{H} 1310 \mathrm{~A}$ & Zilte pionierbegroeiingen(zeekraal) & $>$ & $=$ & \\
\hline $\mathrm{H} 1320$ & Slijkgrasvelden & $=$ & $=$ & \\
\hline $\mathrm{H} 1330 \mathrm{~A}$ & Schorren en zilte graslanden (buitendijks) & $=$ & $=$ & \\
\hline
\end{tabular}




\begin{tabular}{|c|c|c|c|c|}
\hline & & \multicolumn{3}{|c|}{ Gebiedsdoelstelling } \\
\hline & & 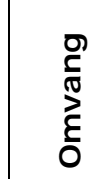 & 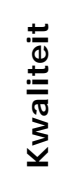 & $\begin{array}{l}\frac{0}{2} \\
\frac{\pi}{5} \\
\frac{0}{0} \\
0 \\
0\end{array}$ \\
\hline H1330B & Schorren en zilte graslanden (binnendijks) & $>$ & $=$ & \\
\hline \multirow[t]{2}{*}{ H7140B } & Overgangs- en trilvenen (veenmosrietlanden) & $>$ & $>$ & \\
\hline & Soorten & & & \\
\hline $\mathrm{H} 1340$ & Noordse woelmuis & $>$ & $=$ & $>$ \\
\hline \multirow[t]{2}{*}{ H1365 } & Gewone zeehond & $=$ & $>$ & $>$ \\
\hline & Broedvogels & & & paren \\
\hline A132 & Kluut & $=$ & $=$ & 2000 \\
\hline A137 & Bontbekplevier & $=$ & $=$ & 100 \\
\hline A138 & Strandplevier & $>$ & $>$ & 220 \\
\hline A191 & Grote stern & $=$ & $=$ & 4000 \\
\hline A193 & Visdief & $=$ & $=$ & 6500 \\
\hline A194 & Noordse stern & $=$ & $=$ & 20 \\
\hline \multirow[t]{2}{*}{ A195 } & Dwergstern & $=$ & $=$ & 300 \\
\hline & Niet-broedvogels & & & $\begin{array}{c}\text { individ } \\
\text { uen }\end{array}$ \\
\hline A004 & Dodaars & $=$ & $=$ & 80 \\
\hline A005 & Fuut & $=$ & $=$ & 370 \\
\hline A007 & Kuifduiker & $=$ & $=$ & 8 \\
\hline A017 & Aalscholver & $=$ & $=$ & 360 \\
\hline A026 & Kleine zilverreiger & $=$ & $=$ & 20 \\
\hline A034 & Lepelaar & $=$ & $=$ & 30 \\
\hline A037 & Kleine zwaan & $=$ & $=$ & \\
\hline A043 & Grauwe gans & $=$ & $=$ & 2300 \\
\hline A045 & Brandgans & $=$ & $=$ & 3100 \\
\hline A046 & Rotgans & $=$ & $=$ & 6300 \\
\hline A048 & Bergeend & $=$ & $=$ & 2900 \\
\hline A050 & Smient & $=$ & $=$ & 12000 \\
\hline A051 & Krakeend & $=$ & $=$ & 130 \\
\hline A052 & Wintertaling & $=$ & $=$ & 1000 \\
\hline A053 & Wilde eend & $=$ & $=$ & 5500 \\
\hline A054 & Pijlstaart & $=$ & $=$ & 730 \\
\hline A056 & Slobeend & $=$ & $=$ & 940 \\
\hline A067 & Brilduiker & $=$ & $=$ & 680 \\
\hline A069 & Middelste zaagbek & $=$ & $=$ & 350 \\
\hline A103 & Slechtvalk & $=$ & $=$ & 10 \\
\hline A125 & Meerkoet & $=$ & $=$ & 1100 \\
\hline A130 & Scholekster & $=$ & $=$ & 24000 \\
\hline A132 & Kluut & $=$ & $=$ & 510 \\
\hline A137 & Bontbekplevier & $=$ & $=$ & 280 \\
\hline A138 & Strandplevier & $=$ & $=$ & 50 \\
\hline A140 & Goudplevier & $=$ & $=$ & 2000 \\
\hline A141 & Zilverplevier & $=$ & $=$ & 4400 \\
\hline A143 & Kanoetstrandloper & $=$ & $=$ & 7700 \\
\hline A144 & Drieteenstrandloper & $=$ & $=$ & 260 \\
\hline A149 & Bonte strandloper & $=$ & $=$ & 14100 \\
\hline A157 & Rosse grutto & $=$ & $=$ & 4200 \\
\hline A160 & Wulp & $=$ & $=$ & 6400 \\
\hline A161 & Zwarte ruiter & $=$ & $=$ & 310 \\
\hline A162 & Tureluur & $=$ & $=$ & 1600 \\
\hline
\end{tabular}




\begin{tabular}{|c|c|c|c|c|}
\hline & & \multicolumn{3}{|c|}{ Gebiedsdoelstelling } \\
\hline & & 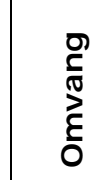 & 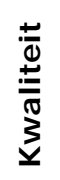 & $\begin{array}{l}\frac{0}{ \pm} \\
\frac{\pi}{3} \\
\frac{0}{0} \\
0\end{array}$ \\
\hline A164 & Groenpootruiter & $=$ & $=$ & 150 \\
\hline A169 & Steenloper & $=$ & $=$ & 580 \\
\hline
\end{tabular}

\subsection{Relevante beschermde natuurwaarden}

Deze paragraaf beschrijft de relevante natuurwaarden met betrekking tot de kweekexperimenten voor off-bottom oesterteelt in de Oosterschelde. De activiteiten met betrekking tot de kweekexperimenten voor off-bottom oesterteelt in de Oosterschelde vinden plaats in het natte deel van het Natura 2000gebied. De terrestrische habitat typen (H1310A, H1320, H1330A, H1330B en H7140B) worden op voorhand niet beïnvloed door de kweekexperimenten en zijn daarmee niet relevant voor deze PB. Dit geldt ook voor de Noordse Woelmuis (H1310). Deze soort kan voorkomen op slikken, maar de gebieden waar de Noordse Woelmuis voorkomt zijn ver verwijderd van de experimenteer locatie (Fig. 7).

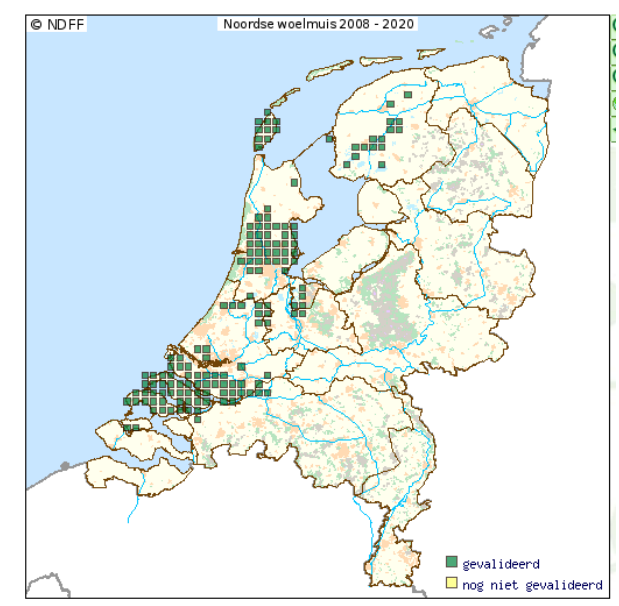

Fig. 7. Verspreiding van de Noordse woelmuis in Nederland (www.telmee.nl).

Het habitattype is $\mathrm{H} 1160$ (Grote baaien), zijnde het habitattype waarbinnen de oesterteelt plaatsvindt, is wel relevant en dus onderwerp van deze PB. Het habitattype is in de Oosterschelde tot stand gekomen door de aanleg van dammen die de zoetwateraanvoer van het oorspronkelijke estuarium beperken. De soortensamenstelling van de Oosterschelde is uniek en verschilt van alle andere grote baaien in Europa.

De Gewone zeehond (H1365) verkeert landelijk in een gunstige staat van instandhouding. Voor de Deltawateren geldt een regiodoelstelling van minstens 200 dieren. Deze doelstelling wordt, mede dankzij immigratie vanuit andere gebieden, met ca. 577 dieren in 2013 ruimschoots gehaald (Wijsman $\&$ Goudswaard, 2015). Een tweede doelstelling is dat de populatie in de Delta zelfstandig levensvatbaar is. In Reed et al. (2003) is een overzicht gegeven van de minimale levensvatbare populatieomvang van een groot aantal vertebraten. De Gewone zeehond komt in dit overzicht niet voor, maar wel is de Grijze zeehond opgenomen. Van deze soort is de minimale levensvatbare populatieomvang 2344 individuen. Het is dus niet te verwachten dat het aantal van 577 Gewone zeehonden in 2013 in de Delta levensvatbaar is en de populatie blijft dus afhankelijk van de migratie uit het Waddengebied. 
Tenslotte zijn er diverse broedvogels en niet-broedvogels die de slikken en platen gebruiken om te foerageren en als hoogwatervluchtplaats of die duikend hun voedsel verzamelen in diepere delen van de Oosterschelde. 


\section{Effectenanalyse}

In dit hoofdstuk worden de te verwachten effecten van het oesterkweekexperiment op de volgende natuurwaarden besproken: Grote baaien, Gewone zeehonden, broed- en niet-broedvogels. Voor ieder van deze natuurwaarden is specifiek gekeken naar de potentiële effecten als gevolg van de kweekactiviteiten.

\subsection{Verstoring van beschermde soorten}

Kweekactiviteiten kunnen vogels en zeehonden verstoren. De activiteiten in het kader van dit project vinden echter niet iedere dag plaats, zijn beperkt in omvang en zijn van korte duur (zie 2.2.4). $\mathrm{Er}$ wordt geen geluidsapparatuur, anders dan ten behoeve van communicatiedoeleinden, gebruikt. Anderzijds kunnen kweeksystemen ook positieve effecten op beschermde soorten hebben, omdat ze dienen als kunstmatige rustplaats (Kamermans et al., 2014), beschutting leveren of mogelijk ook voedsel in de vorm van vissen en macroalgen aantrekken. Verstoring van vogels door gebruik van verlichting is bij oesterteelt niet aan de orde.

Visuele verstoring betreft verstoring door de aanwezigheid en/of beweging van mensen dan wel voorwerpen die niet thuishoren in het natuurlijke systeem. Visuele verstoring leidt vooral tot vluchtgedrag van dieren. De soort reageert bijvoorbeeld op beweging omdat een potentiële vijand wordt verwacht. Andersom kan optische verstoring juist ook het uitzicht van soorten beperken waardoor zij potentiële vijanden niet zien naderen. De oesterteelt experimenten worden in het sublitoraal uitgevoerd waardoor alleen de boeien van de longlines met mandjes te zien zullen zijn. De kooien die op de bodem zijn geplaatst komen alleen met laagwater boven water. Visuele verstoring is dus minimaal.

De werkzaamheden ten behoeve van het kweken van oesters kunnen door het daarbij geproduceerde geluid en de bewegingen leiden tot een tijdelijke verstoring van de in het gebied aanwezige fauna. Dat geldt ook voor het geluid (incl. trillingen) en de beweging van het schip waarmee het systeem wordt geplaatst en onderhouden. Het geluid door de oesterkweek en de bijbehorende scheepvaart bestaat uit geluid boven water en onder water. Geluid boven water kan tot verstoring van vogels leiden. Onderwatergeluid kan leiden tot verstoring van vissen en zeezoogdieren. Daar de kweek plaatsvindt op reguliere oesterpercelen is geen sprake van extra verstoring door varende schepen. De activiteit is locatie gebonden, kleinschalig en beperkt in de tijd. Er wordt gemiddeld 2 maal per maand over een periode van 2-4 uur gewerkt. Het gaat uitsluitend om verstoring van tijdelijke aard, aangezien de activiteit van korte duur is en de verstoring ophoudt zodra de activiteit is voltooid. Daarnaast is de motor van het schip uit als er gewerkt wordt aan de off-bottom kweekopstellingen, terwijl bij het gebruik als bodemcultuur kweekperceel de motor aan is als er gezaaid of gevist wordt. Daarom is de verwachting dat er geen sprake is van extra verstoring door de voorgestelde off-bottom kweekexperimenten. Ook de populatiedynamiek van beschermde soorten wordt niet verstoord.

\subsection{Verontreiniging}

Bij het kweken van oesters en het oogsten ervan komen geen chemische stoffen in het water. De oesterteelt vindt plaats in kunststof zakken en manden. De kooien zijn gemaakt van betonijzer en de lijnen voor manden zijn van nylon en bevestigd aan PE drijvers. Door stormen gepaard met grote golfkracht raken deze materialen of delen daarvan soms los en komen dan in het ecosysteem terecht. Ook bestaat de kans dat door werkzaamheden, als uitdunnen en oogsten of door verwering, kleine partikels (microplastics) in het ecosysteem terecht komen. Daarbij is het mogelijk dat deze deeltjes vervolgens opgenomen worden door filtrerende organismen (b.v. oesters of mosselen) of door sediment etende organismen (b.v. wormen). Recent onderzoek laat zien dat mosselen microplastics 
uit het water kunnen filtreren (Wegner et al., 2012). De zakken en manden worden doorgaans na 5 jaar vervangen. Er wordt geen afval achter gelaten. De te gebruiken installaties zijn deugdelijk van constructie. Er zijn geen aanwijzingen dat slijtage van de materialen effecten zullen hebben op het ecosysteem. Indien overmatige slijtage van de kunststof wordt geconstateerd, worden deze binnen een maand vervangen. Op basis van de beschikbare kennis en mitigerende maatregelen worden geen als significante nadelige effecten verwacht op de instandhoudingsdoelen.

De geplande experimenten gaan gepaard met scheepsbewegingen van en naar het gebied met percelen. Op het perceel zal het schip stil liggen om de werkzaamheden aan de zakken en manden te kunnen uitvoeren. Het monitoren van scheepsbewegingen is onderdeel van het monitoringprogramma (zie onderzoeks- en monitoringplan in bijlage 1). De Aerius calculator

(https://calculator.aerius.nl/calculator/) berekent de stikstofuitstoot voor verschillende menselijk activiteiten. Een Aerius berekening is uitgevoerd voor de categorie koelschepen en vissersschepen en deze geeft aan "There are no nature areas with calculation result higher than the threshold". Extra stikstofdepositie is dus niet aan de orde.

\subsection{Verandering dynamiek substraat}

Het aangewezen habitattype in de Oosterschelde is H1160 Grote baaien. Typische soorten van dit habitat type kunnen beïnvloed worden door de voorgenomen activiteit. Schelpdieren filtreren organische en anorganische deeltjes uit het water. Slechts een deel van het gefilterde materiaal wordt verteerd in het maag-darm kanaal waarbij de restproducten worden uitgescheiden als faeces. De rest gaat niet door het maag-darmkanaal, en wordt daarvoor reeds verwijderd als pseudofaeces.

Pseudofaeces en faeces bezitten relatief hoge gehaltes aan organische stof. Ze bezinken richting bodem (depositie) en worden tijdens dit proces door de waterstroming meegevoerd en verspreid, vaak ook weer opgewerveld en verder gevoerd tot ze opnieuw bezinken (de Mesel et al., 2008). Het organisch rijker worden van de bodem als gevolg van depositie kan leiden tot verandering van de omstandigheden voor soorten die in arme omstandigheden voorkomen. Andere soorten kunnen juist baat hebben bij depositie en verrijkte omstandigheden. Bepalende factoren daarbij zijn de mate waarin golven en stroming organisch materiaal verspreiden en de kwetsbaarheid van het natuurlijk bodemleven.

De experimenten met de off-bottom teelt van oesters zijn gepland op oesterkweekpercelen op een schaal die veel kleiner is dan de perceelschaal. In het totaal nemen de kooien niet meer dan 10 tot 20 $\%$ van het perceel oppervlak in beslag. Hier vond al oesterteelt plaats. Vanwege de kleine omvang van het experiment is de verwachting dat er geen significante effecten van veranderingen in stroming rond de lijnen met mandjes en de kooien zal optreden. Daarom wordt geen verandering in dynamiek van het substraat als gevolg van bezinken van pseudofaeces en faeces verwacht. Om dit te kunnen verifiëren is de monitoring van het slibgehalte in de bodem onderdeel van het monitoringprogramma (zie onderzoeks- en monitoringplan in bijlage 1 ).

\subsection{Verandering soortensamenstelling}

De kooien en manden worden in het sublitoraal van de Oosterschelde geplaatst. Doordat de bodem eerder in gebruik was voor bodemcultuur van oesters zal er geen effect zijn op de kwaliteit van het bodemhabitat.

\subsection{Verstoring of verlies oppervlakte}

Oesterkweek in zakken kan effect hebben op de kwaliteit van het habitattype H1160 door beïnvloeding van natuurlijke processen (stromingspatronen, sedimentatie en erosie). Het project met de oesterkweek vindt plaats boven oesterpercelen en heeft hierdoor geen ínvloed op de omvang van het Habitattype 1160. Doordat er voor de lijnen met mandjes ankers in de bodem worden aangebracht is er feitelijk sprake van verstoring van een habitatoppervlakte van enkele vierkante meters. Ten 
opzichte van het oppervlakte van de Oosterschelde is dit met zekerheid niet relevant. Indien ankers worden verwijderd, zal ter plaatse met zekerheid herstel van de bodem en het bodemleven optreden. Het effect is derhalve niet onomkeerbaar.

De ligging van de zoutgradiënt, uitgedrukt als de verhouding zout en brak gebied binnen habitattype 1160, wijzigt niet. De water(bodem)kwaliteit, uitgedrukt als de concentraties nutriënten en milieuvreemde stoffen, wijzigt eveneens niet.

De voorgenomen activiteit heeft geen significant effect op het ontstaan van meerjarige stabiele mosselbanken, aangezien er niet op de bodem wordt gevist. Ook voor het uitgangsmateriaal worden alleen oestertjes gebruikt die niet afkomstig zijn uit gebieden met meerjarige stabiele mosselbanken of oude oesterbanken.

Oesters filtreren organische en anorganische deeltjes uit het water. Deze filtratiedruk kan de draagkracht van de voedselketen beïnvloeden (zie Kamermans et al., 2014; Smaal et al., 2013). Effecten op de draagkracht en op de instandhoudingsdoelen worden niet verwacht vanwege de volgende redenen:

- Het totale areaal aan oesterbanken op droogvallende platen in de Oosterschelde is in het voorjaar van 2014 door WMR (IMARES) geschat op 652 hectare in 2014 en 614 hectare in 2015. Daarmee lijkt het areaal met 127 hectare (16\%) afgenomen ten opzichte van 2013 (van den Ende et al., 2014, van den Ende et al.,2016). Een deel van deze afname (ca. 43 ha) wordt verklaard uit het feit dat de sublitorale oesters (op percelen en op de bank bij Kattendijke) buiten beschouwing zijn gelaten. De rest van de afname kan verklaard worden doordat het areaal aan oesterbanken in de kom van de Oosterschelde is afgenomen. Ten opzichte van 2013 ligt er 89 hectare minder aan oesterbanken. Deze afname wordt waarschijnlijk veroorzaakt door het wegvissen van Japanse oesters in dit gebied. In de rest van de Oosterschelde lijkt het areaal aan oesterbanken stabiel (van den Ende et al., 2014, 2016).

- De hoeveelheid oesters is afhankelijk van het succes van de broedval en de mortaliteit. Er is de laatste jaren overal in de Oosterschelde sterfte onder éénjarige oesters als gevolg van het oester herpes virus, waardoor het bestand aan oesters op de kweekpercelen laag is. Er is hierdoor geen sprake van een volledige bezetting van de kweekpercelen. De draagkrachtberekeningen voor de Oosterschelde gaan uit van een worst-case scenario, waarbij ervan uitgegaan wordt dat de percelen volledig benut worden. Dit is al jaren niet het geval. Het project is tijdelijk en de verwachting is dat bovenstaande situatie in de komende paar jaar niet zal veranderen.

- In het project gaat het om een kleine hoeveelheid oesters op oesterpercelen; op het totaal van $10 \mathrm{mln} \mathrm{kg}$ bedraagt de extra stock 0,24 $\mathrm{mln} \mathrm{kg}$; ten opzichte van een totale geschatte voorraad op de percelen van $10 \mathrm{mln} \mathrm{kg}$ is dat 2,4\%. De off-bottom teelt vindt plaats op oesterpercelen. Op de bodem van deze percelen worden geen oesters gekweekt als de installaties daar geplaatst zijn. De grondstof voor de kweek komt uit het systeem (wilde oesterbanken of van de kweekpercelen).

- De verwachting is dat off-bottom oesters iets sneller groeien, daarnaast bevatten de installaties meer oesters dan op hetzelfde oppervlak op de bodem gekweekt zouden worden. Dit vergoot de efficiëntie van de oesterkweek. Dat is een van de doelstellingen van het Plan van Aanpak 'Oester-maatregelen' 2016 - 2018 (NOV, 2016).

Op grond van het bovenstaande komen wij tot de conclusie dat er geen effect is op de draagkracht. In navolging van de meerjarige productie- en effectmetingen aan mosselzaadinvanginstallaties ( $M Z I$ 's) (project 2009-2013; Kamermans et al. 2014), loopt er momenteel een programma ('Draagkracht MZI') in opdracht van het ministerie van EZ (Kamermans \& van Asch, 2016). De centrale vraag bij dit onderzoek is: Heeft de opschaling van MZI's effect op de draagkracht voor schelpdieren in de Waddenzee en Oosterschelde? Monitoring is van belang om mogelijke effecten van de opschaling zichtbaar te maken en te kunnen evalueren. De indicatoren voor een veranderende draagkracht die worden onderzocht, zijn het vleesgehalte van aangevoerde mosselen en de groei van kokkels zoals die blijkt uit de jaarlijkse surveys. Het gebruik van de draagkrachtindicatoren werkt als volgt: een afname van het vleesgehalte van mosselen en een afname van de groei van kokkels wijzen op een afname 
van de draagkracht voor schelpdieren. Uit Smaal et al. (2013) blijkt dat vleesgehalte een goede indicatie van draagkracht is. Met dit onderzoek is het mogelijk een vinger aan de pols te houden. Analyse van de data tot en met 2014 laat zien dat het vleesgehalte van mosselen en de groei van kokkels in de Oosterschelde fluctueert in ruimte en tijd, maar geen trend in de tijd vertoont (Kamermans \& van Asch, 2016).

Effecten op de kwaliteit van habitattype 1160 (grote ondiepe kreken en baaien) zijn niet te verwachten, omdat door de voorgenomen activiteit het oppervlak of de kwaliteit van het habitattype niet wordt aangetast. Tevens is geen negatief effect op vissen is te verwachten, daar de kweek geheel in zakken plaatsvindt.

\subsection{Vogels}

De oesters worden gekweekt in zakken en mandjes in het sublitoraal van de Oosterschelde. In de omgeving van de installaties wordt door diverse vogelsoorten gefoerageerd. Het betreft soorten die in het water foerageren. Voor de overige vogels uit de doelsoortenlijst (zie paragraaf 4.1) zijn foerageergebieden en biotopen aanwezig in de buurt van de geplande activiteit. De werkzaamheden worden echter rondom hoogwater uitgevoerd. De platen zijn dan niet bereikbaar voor foeragerende steltlopers en andere op de platen foeragerende vogels. Er worden dus geen effecten verwacht voor op platen foeragerende vogels. Broedgebieden van de soorten broedvogels uit tabel 2 (Kluut, Bontbekplevier, Strandplevier, Grote stern, Visdief, Noordse stern, Dwergstern) komen niet voor binnen $500 \mathrm{~m}$ van de werkingssfeer van de oesterkweeksystemen in het Windgat (http://www.synbiosys.alterra. nl/natura2000/gebiedendatabase.aspx?subj=profielen ). Daarom worden geen effecten verwacht op geen van de beschermde broedvogelsoorten.

De locaties liggen op meer dan $500 \mathrm{~m}$ van de hoogwatervluchtplaatsen, daardoor wordt geen effect verwacht.

De soorten die in het water foerageren, in het deel van de Oosterschelde waar de oesterkweeksystemen zich bevinden, zijn (data RWS tellocaties OS622 en OS 6211):

A005 Fuut

A017 Aalscholver

A043 Grauwe gans

A045 Brandgans

A048 Bergeend

A050 Smient

A051 Krakeend

A053 Wilde eend

A054 Pijlstaart

A056 Slobeend

A069 Middelste zaagbek

A103 Slechtvalk

Voor alle soorten geldt een behoudsdoelstelling voor omvang en kwaliteit (tabel 2 in paragraaf 4.1).

Gelet op de wijze van kweken, in gesloten zakken en manden met kleine openingen, kunnen vogelsoorten die duikend hun voedsel bemachtigen niet bij de oesters. Overigens vormen voor geen van de doelsoorten oesters (preferent) voedsel. Gezien de aard van de activiteit en het feit dat oesters geen belangrijke voedselbron vormen, is niet te verwachten dat het voedselaanbod voor deze soorten door de oesterkweek zal afnemen.

De vormgeving van de kooien met zakken en manden en longlines met manden is zodanig dat vogelsoorten welke al duikend hun voedsel bemachtigen er niet in verstrikt kunnen raken. Tijdens elk bezoek worden de systemen gecontroleerd op vogelslachtoffers.

Tijdens de werkzaamheden op de kweeklocatie in het sublitoraal van de Oosterschelde kunnen in beginsel vogels worden verstoord. Voor de vogels die op het open water verblijven zal de verstoring 
echter minimaal zijn, aangezien zij ruime mogelijkheden hebben om bij verstoring in de omgeving een alternatieve verblijfplaats te vinden en de activiteit zeer lokaal en tijdelijk is. De drijvers kunnen dienen als rustplaats voor de vogels. Er zijn geen als significant te beoordelen effecten op vogels en de omvang van hun leefgebied te verwachten; het monitoren van vogels is onderdeel van het monitoringprogramma (zie onderzoeks- en monitoringplan in bijlage 1 ).

\subsection{Habitatsoorten}

De Oosterschelde is voor een tweetal habitatsoorten aangewezen: de Gewone zeehond (H1365) en de Noordse woelmuis (H1340). De Noordse woelmuis komt niet voor in het gebied waar het project plaatsvindt (Fig. 7).

De Oosterschelde heeft voor zeehonden een functie als voedsel- en verblijfgebied. Voor het vervullen van deze functies zijn platen met aanliggende diepe geulen van belang. Het werpen van jongen vindt plaats op rustig gelegen platen. Zeehondenligplaatsen bevinden zich in het midden en het westen van de Oosterschelde. In de buurt van de kweeklocatie zijn geen opgroei- en rustgebieden van de zeehond gesitueerd, waardoor geen significante effecten op de populatie Gewone zeehonden te verwachten zijn (Wijsman \& Goudswaard, 2015). 


\section{$6 \quad$ Mitigerende maatregelen}

De te gebruiken installaties zijn deugdelijk van constructie. Indien overmatige slijtage van de kunststof wordt geconstateerd worden deze binnen een maand vervangen. Er wordt geen geluidsapparatuur anders dan ten behoeve van communicatiedoeleinden gebruikt. Er wordt geen afval achtergelaten. De werkzaamheden worden bij daglicht uitgevoerd. Tijdens elk bezoek worden de systemen gecontroleerd op vogelslachtoffers. Door de teelt in zakken en manden wordt predatie door oesterboorders voorkomen. 


\section{$7 \quad$ Cumulatieve effecten}

Als uitgangsmateriaal worden kleine oesters en oesterbroed gebruikt afkomstig is van de reguliere oesterkweek en van visserij op de vrije gronden waar vergunning voor is verleend. De off-bottom teelt vindt plaats op oesterpercelen. Op de bodem van deze percelen worden geen oesters gekweekt als de installaties daar geplaatst zijn. De verwachting is dat off-bottom oesters iets sneller groeien, daarnaast bevatten de installaties meer oesters dan op hetzelfde oppervlak op de bodem gekweekt zouden worden. De off-bottom productie van oesters vergroot op die manier het bestand aan schelpdieren in de Oosterschelde. Dit kan via een extra beslag op het aanwezige voedsel (microalgen) een effect hebben op de instandhoudingsdoelen voor de beschermde natuurwaarden en kenmerken. Boven een bepaalde graasdruk door schelpdieren kan de beschikbaarheid van microalgen minder worden. Dit kan doorwerken in een verminderde groei van de schelpdieren die op hun beurt weer als voedsel dienen voor bepaalde vogelsoorten. Het effect wordt bepaald door de mate van waterverversing, het niveau van de algenproductie en de filtratiedruk vanuit de natuur en schelpdierkweek. Er is geen vaste draagkrachtdrempel te bepalen, omdat de beschikbaarheid van algen van vele factoren tegelijkertijd afhankelijk is (de watertemperatuur, de hoeveelheid licht in het water, de hoeveelheid voedingsstoffen voor de algen, de aanwezigheid van andere soorten die algen eten (schelpdieren, zoöplankton, etc.)). Wel kan worden aangegeven in hoeverre de voorgenomen activiteit een substantiële bijdrage kan leveren in het vergroten van de hoeveelheid schelpdieren die algen eten, of in hoeverre de vergroting wegvalt in de ruis rondom de voedselbeschikbaarheid die wordt veroorzaakt door de andere bovengenoemde factoren. Een effect op de draagkracht (voedselbeschikbaarheid) kan een doorwerking hebben op de beschermde soorten wanneer hierdoor de groei van natuurlijke schelpdierbestanden wordt beïnvloed (schelpdieretende vogels) ofwel de beschikbaarheid van microalgen via schakels als zoöplankton effecten heeft via de voedselketen (overige soorten). Voor de N2000-doelen gaat het met name om schelpdieretende vogels. Deze foerageren op droogvallende platen en eten voornamelijk kokkels. De toename van het bestand zal maximaal ca 2,4\% bedragen ten opzichte van het totaal. Uit voorzorg kan een eventueel effect op draagkracht worden gemitigeerd door het wegvissen van wilde oesters. Hierbij kan zoveel biomassa worden weggevist als maximaal aanwezig zal zijn bij oogst. Omdat de experimenten geheel op oesterpercelen plaatsvinden, wordt ook het areaal niet significant vergroot. In opdracht van het ministerie van Economische Zaken wordt in het kader van het mosselconvenant de draagkracht van de Oosterschelde voor schelpdieren gemonitord (Kamermans \& van Asch, 2016). Met dit onderzoek is het mogelijk een vinger aan de pols te houden. De methode is operationeel (project gefinancierd door EZ) en gebaseerd op studies die zijn uitgevoerd gedurende het project Meerjarige effect- en productiemetingen aan MZI's in de Westelijke Waddenzee, Oosterschelde en Voordelta (ook gefinancierd door EZ, Kamermans et al, 2014).

Er wordt geen effect verwacht op het leefgebied van op het water levende vogels door de geplande experimenten en vaarbewegingen. Er bevinden zich geen mosselzaadinvanginstallaties (MZI's) en mosselhangcultures (MHCs) in dit deel van de Kom van de Oosterschelde. Een cumulatief effect door de aanwezigheid van MZI's en MHCs wordt dan ook niet verwacht. De geplande experimenten gaan gepaard met scheepsbewegingen van en naar de proeflocatie. De proeflocatie bevindt zich in de Kom van de Oosterschelde. Dit is een gebied waar dagelijks vaarbewegingen plaats vinden in verband met werk op de percelen.

De zandhonger van de Oosterschelde wordt niet vergroot door de oesterkweekinstallaties. Verandering in slibgehalte zal niet significant zijn. 


\section{Conclusie}

Experimentele oesterkweek op reguliere oesterkweekpercelen Windgat perceelnummers 13, 14 en 16 in het sublitoraal van de Kom van de Oosterschelde is geanalyseerd wat betreft de effecten op de Natura 2000-instandhoudingsdoelstellingen van habitats en soorten. Ook is ingegaan op mitigerende maatregelen en cumulatieve effecten.

De conclusie is dat er op basis van de beschikbare informatie die in voorliggende Passende Beoordeling is samengevat geen als significant te beoordelen negatieve effecten worden verwacht van experimentele oesterkweek op oesterkweekpercelen Windgat 13, 14 en 16 in het sublitoraal van de Kom van de Oosterschelde op de Natura 2000-instandhoudingdoelstellingen van habitats en soorten en aan de orde zijnde verbeteropgaven voor deze gebieden. 


\section{Kwaliteitsborging}

Wageningen Marine Research beschikt over een ISO 9001:2008 gecertificeerd kwaliteitsmanagementsysteem (certificaatnummer: 187378-2015-AQ-NLD-RvA). Dit certificaat is geldig tot 15 september 2018. De organisatie is gecertificeerd sinds 27 februari 2001. De certificering is uitgevoerd door DNV Certification B.V. 


\section{Literatuur}

Dundon, W.G., I. Arzul, E. Omnes, M. Robert, C. Magnabosco, M. Zambon \& G. Arcangeli (2011). 'Detection of Type 1 Ostreid Herpes variant (OsHV-1 $\mu$ var) with no associated mortality in Frenchorigin Pacific cupped oyster Crassostrea gigas farmed in Italy'. In: Aquaculture, 314(1), 49-52.

Faasse, M. A. \& M. Ligthart (2009). American (Urosalpinx cinerea) and Japanese oyster drill (Ocinebrellus inornatus) (Gastropoda: Muricidae) flourish near shellfish culture plots in The Netherlands. Aquatic Invasions 4: 321-326.

Janssen, J.A.M. \& J.H.J. Schaminée (2009). Europese natuur in Nederland. Natura 2000-gebieden van Zee en Kust. Zeist, KNNV Uitgeverij.

Kamermans, P., M. Poelman \& M.Y. Engelsma (2013). Oesterherpesvirus: een overzicht. IMARES, Rapportnummer: Factsheet, 2 pagina's.

Kamermans, P., C. Smit, J. Wijsman \& A. Smaal (2014). Meerjarige effect- en productiemetingen aan MZI's in de Westelijke Waddenzee, Oosterschelde en Voordelta: samenvattend eindrapport. I MARES Rapport C191/13.

Kamermans P. \& M. van Asch (2016). Monitoring draagkracht voor schelpdieren in relatie tot opschaling MZIs in de Waddenzee en Oosterschelde tot en met 2014. I MARES Rapport C046/16.

Kamermans P. \& A. Smaal (2016). Passende beoordeling ten behoeve van experimentele oesterkweek in het sublitoraal van de Kom van de Oosterschelde. IMARES rapport C013/16.

Mesel I. De, Meesters H.W.G., Meijboom A. \& Wijsman J.W.M. (2008). Impact van MZI's op organische koolstof in de bodem. I MARES Rapport C037/08.

Ministerie van LNV (2004). Ruimte voor een zilte oogst. Naar een omslag in de Nederlandse schelpdiercultuur. Beleidsbesluit Schelpdiervisserij 2005 - 2020. Ministerie van Landbouw, Natuur en Voedselkwaliteit, Rapport, 46 pagina's.

Ministerie van LNV (2009). Definitief aanwijzingsbesluit Natura 2000-gebied Oosterschelde. Ministerie van Economische Zaken, Landbouw en Innovatie, Rapport.

Ministerie I enM (2015). Natura 2000 Deltawateren Ontwerpbeheerplan Deltawateren 2015-2021 Oosterschelde, Ministerie van Infrastructuur en Milieu | Rijkswaterstaat. Rapport, 95 pagina's.

NOV (2016) Plan van Aanpak 'Oester-maatregelen' 2016 - 2018.

Reed, D.H.J., J. O'Grady, B.W. Brook, J.D. Ballou \& R. Frankham (2003). Estimates of minimum viable population sizes for vertebrates and factors influencing those estimates. Biological Conservation 113: 23-34.

Smaal A.C., P. Kamermans \& W.J. Strietman (2016). Kennis en onderzoeksagenda voor de Nederlandse oestersector. I MARES Rapport C057/16.

Smaal A.C., T. Schellekens, M.R. van Stralen \& J.C. Kromkamp (2013). Decrease of the carrying capacity of the Oosterschelde estuary (SW Delta, NL) for bivalve filter feeders due to overgrazing? Aquaculture 404-405: 28-34.

Strietman, W.J., A. Smaal \& B. Bolman (2016). Economische situatie van de oestersector. Potentiele impact van herpesvirus in oesters en Japanse oesterboorder op de oestersector. Quickscan, LEI .

Troost, K. \& H. Van Hulzen (2009). Doelendocument Natura 2000 Deltagebied. Uitwerking van Natura 2000 waarden in omvang, ruimte en tijd, Rapport, 233 pagina's.

Van Bentum, D. \& E. Koolmees (2014). Natura 2000-ontwerpbeheerplan Deltawateren 2015-2021 Oosterschelde (5e concept). Royal Haskoning DHV, Rapport, 69 pagina's.

Van den Ende D., M. van Asch, E.B. Brummelhuis \& K. Troost (2014). Japanse oesterbanken op droogvallende platen in de Nederlandse kustwateren in 2014: bestand en arealen. IMARES Rapport: C172/14.

Van den Ende, D., E. Brummelhuis, C. Van Zweeden, M. Van Asch \& K. Troost (2016). Mosselbanken en oesterbanken op droogvallende platen in de Nederlandse kustwateren in 2015: bestand en arealen, Rapport nummer: IMARES rapport C168/15, 45 pagina's).

Van Maldegem, D. (2004). Ontwikkeling morfologie Oosterschelde in relatie tot zandhongerproblematiek; RIKZ/AB/2004.809x; juli 2004.

Van Stralen, M.R., K. Troost \& A. Gitttenbrerger (2015). Vindplaatsen oesterboorders, najaar 2015. Memo PO Mosselcultuur. 
Wegner A., E. Besseling, E.M. Foekema, P. Kamermans \& A.A. Koelmans (2012). Effects of Nanopolystyrene on the Feeding Behaviour of the Blue Mussel (Mytilus edulis L.). Environmental Toxicology and Chemistry 31: 2490-2497.

Wijsman, J.W.M. \& P.C. Goudswaard (2015). Passende Beoordeling vaste vistuigvisserij in de Oosterschelde. Wageningen IMARES, Rapport nummer: C127/15, 69 pagina's. 


\section{Verantwoording}

Rapport C031/17

Projectnummer: 4313200001

Dit rapport is met grote zorgvuldigheid tot stand gekomen. De wetenschappelijke kwaliteit is intern getoetst door een collega-onderzoeker en het verantwoordelijk lid van het managementteam van Wageningen Marine Research

Akkoord:

Dr. J. Wijsman

Senior onderzoeker

Handtekening:

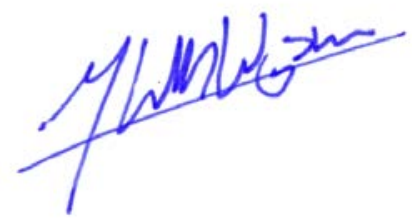

Datum:

6 april 2017

Akkoord:

Drs. J. Asjes

Manager I ntegratie

Handtekening:

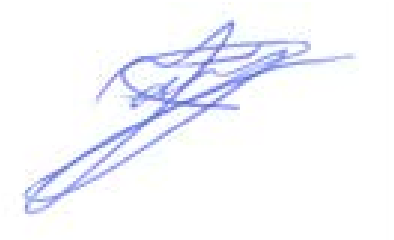

Datum:

6 april 2017 


\section{Bijlage 1 Begeleiding OesterKweek eXperimenten (BOKX)}

Eind maart 2016 heeft WMR (IMARES) een convenant gesloten met o.a. de Nederlandse Oestervereniging. In het kader daarvan is in juli 2016 het project Begeleiding OesterKweek eXperimenten (BOKX) gestart en een werkplan opgesteld. Onderdeel daarvan is monitoring ten behoeve van vergunning voor off-bottom experimenten in sublitoraal van de Kom van de Oosterschelde. Dit betreft:

a. WMR rapporteert het relatieve verschil in scheepsbewegingen en verbruik van gasolie tussen offbottom kweek en bodemcultuur. Kwekers leveren de hiervoor benodigde gegevens aan. WMR zal zorgdragen voor validatie van de gegevens door een vergelijking met informatie uit andere landen uit te voeren. De resultaten zullen worden teruggekoppeld aan de werkgroep off-bottom oesterteelt.

b. Voor de aanwezigheid van beschermde vogelsoorten op en nabij de experimenten in vergelijking met aanwezigheid op bodempercelen wordt een identificatie protocol opgesteld. Ook zal instructie aan boord plaatsvinden door WMR medewerkers. Daarnaast zal WMR tellingen uitvoeren op dagen dat de kwekers wel en niet aan het werk zijn. De resultaten zullen worden teruggekoppeld aan de werkgroep off-bottom oesterteelt. De onderzoeksvraag betreft: Is er verschil in aanwezigheid van beschermde vogelsoorten op en nabij de experimenten tijdens het uitvoeren van werkzaamheden in vergelijking met aanwezigheid van vogels op bodempercelen bij afwezigheid van werkzaamheden?

c. Een systematische monitoring van een groep uniforme oesters die op verschillende plaatsen en in verschillende systemen zijn uitgezet kan een beeld geven van het succes van off-bottom teelt in vergelijking met bodemcultuur. De te meten parameters betreffen groei, vleesgehalte, ontwikkeling van de schelp (vorm, dikte) en sterfte van de oesters en omvang van aangroei. Door verschillende locaties te vergelijken kan de invloed van locatie, diepte, stroming etc. worden bepaald. WMR kan voor de monstername een protocol voor de kwekers opstellen en de monsters van off-bottom teelt en bodemcultuur analyseren. Na iedere monstername kunnen de resultaten worden teruggekoppeld aan de werkgroep off-bottom oesterteelt.

Indien de vergunning voor de experimenten in het Windgat wordt verleend, zal de monitoring daarvan ook worden opgenomen. Dit betreft dan naast bovengenoemde metingen ook onderzoek naar consequenties van kooien met zakken en manden en longlines voor manden en met betrekking tot 'leefgebied en soorten' (verandering slibgehalte). 
Wageningen Marine Research

T: +31(0)317480900

E: marine-research@wur.nl

www.wur.nl/marine-research

Visitors address

- Ankerpark 271781 AG Den Helder

- Korringaweg 5, 4401 NT Yerseke

- Haringkade 1, 1976 CP IJ muiden
Wageningen Marine Research is the Netherlands research institute established to provide the scientific support that is essential for developing policies and innovation in respect of the marine environment, fishery activities, aquaculture and the maritime sector.

Wageningen University \& Research is specialised in the domain of healthy food and living environment.

The Wageningen Marine Research vision:

'To explore the potential of marine nature to improve the quality of life.'

The Wageningen Marine Research mission

- To conduct research with the aim of acquiring knowledge and offering advice on the sustainable management and use of marine and coastal areas.

- Wageningen Marine Research is an independent, leading scientific research institute.

Wageningen Marine Research is part of the international knowledge organisation Wageningen UR (University \& Research centre). Within Wageningen UR, nine specialised research institutes of Stichting Wageningen Research (a Foundation) have joined forces with Wageningen University to help answer the most important questions in the domain of healthy food and living environment. 